\section{Удк 336.71}

JEL classification: G21, G28

\section{ТетЯна ГОНЧАРЕНКО}

кандидат економічних наук, директор

Сумський коледж економіки і торгівлі, Україна

E-mail: t_p_goncharenko@ukr.net http://orcid.org/0000-0001-6298-4517 http://www.researcherid.com/rid/AAI-59472020

(C) Тетяна Гончаренко, 2020

Отримано: 20.01.2020 p.

Прорецензовано: 02.02.2020 p. Рекомендовано до друку: 26.02.2020 р. Опубліковано: 28.02.2020 p.

\section{(c) (7) (8)}

Ця стаття розповсюджується на умовах ліцензії Creative Commons AttributionNonCommercial 4.0, яка дозволяє необмежене повторне використання, розповсюдження та відтворення на будь-якому носії, за умови правильного цитування оригінальної роботи
Тетяна Гончаренко (Україна)

\section{АНАЛІЗ МОДЕЛЕЙ БІЗНЕС- СТРАТЕГІЇ БАНКІВ: МІЖНАРОДНИЙ ТА ВІТЧИЗНЯНИЙ ДОСВІД}

\author{
АНОТАЦІя
}

Вступ. В сучасних умовах розвитку банки перебувають під впливом численної кількості зовнішніх факторів міжнародного і національного рівня, а також економічного, політичного, соціального та технологічного спрямування, що сприяють необхідності видозміни особливостей їх діяльності. До них в першу чергу відносять перегляд бізнес-стратегій банків як основних відображень їх діяльності, а також застосування більш ефективних їх видів відповідно від специфіки установи. Дане питання $\epsilon$ об'єктом численних досліджень як вітчизняних, так і зарубіжних науковців та потребує детального вивчення та зумовлює актуальність обраної теми.

Метою дослідження є ґрунтовний аналіз існуючих моделей бізнес-стратегії банків в міжнародному та вітчизняному банківському просторі.

Метод (методологія) представлена у вигляді загальнонаукових та спеціальних методів: аналіз і синтез, порівняння та групування, індукція та дедукція, логічне узагальнення тощо.

Результати. В роботі досліджено основні тенденції в зміні основних моделей бізнес-стратегії банків на прикладі США та Європи, що проявлялося в характерній трансформації їх складових балансів та виявлено найбільш поширені їх види (наприклад, інвестиційний банкінг, рітейл банкінг, стратегія орієнтована на міжбанківські операції тощо). Автор ідентифікує різні типи бізнес-стратегії в Україні та наводить основні їх характеристики (наприклад, універсальний банкінг, рітейл банкінг, корпоративний банкінг, рітейл фінансування, інвестиційні та заморожені банки тощо). В результаті зроблено висновок, що між вітчизняними та міжнародними моделями бізнес-стратегій існує різниця, що зумовлена специфікою розвитку економіки, умовами виходу із кризи тощо та це розкриває шляхи щодо вдосконалення.

Гончаренко Т. П. Аналіз моделей бізнес-стратегії банків: міжнародний та вітчизняний досвід. Економічний аналіз. 2020. Том 30. № 1. Частина 1. С. 4249.

DOI: https://doi.org/10.35774/econa2020.01.01.042

Ключові слова: бізнес-стратегія; бізнес-моделі, банк; банкінг; банківська стратегія. 
UDC 336.71

JEL classification: G21, G28

\section{Tetiana GONCHARENKO}

PhD in Economics,

Director,

Sumy College of Economics and Trade, Ukraine

E-mail:t_p_goncharenko@ukr.net

http://orcid.org/0000-0001-6298-4517

http://www.researcherid.com/rid/AAI-5947-

2020

(C) Tetiana Goncharenko, 2020

Received: 20.01.2020

Revised: 02.02.2020

Accepted: 26.02.2020

Online publication date: 28.02 .2020

\section{(c) (7) (5)}

This is an Open Access article, distributed under the terms of the Creative Commons AttributionNonCommercial 4.0 license, which permits unrestricted re-use, distribution, and reproduction in any medium, provided the original work is properly cited.
Tetiana Goncharenko (Ukraine)

\section{ANALYSIS OF MODELS OF BANKING BUSINESS STRATEGY: INTERNATIONAL AND DOMESTIC EXPERIENCE}

\begin{abstract}
Introduction. In the current conditions of development, banks are influenced by numerous external factors at the international and national level, as well as economic, political, social and technological trends, which contribute to the need to change the features of their activities. These include, first of all, the review of banks' business strategies as the main reflections of their activities, as well as the use of more effective types of them in accordance with the specifics of the institution. This issue is the subject of extensive research by both domestic and foreign scientists and requires detailed study and determines the relevance of the chosen topic.

The purpose of the study is a thorough analysis of existing models of business strategy of banks in the international and domestic banking space.

The method (methodology) is presented in the form of general and special methods: analysis and synthesis, comparison and grouping, induction and deduction, logical generalization, etc.

Results. The paper examines the main trends in changing the basic business strategy models of banks in the example of the USA and Europe, which manifested in the characteristic transformation of their component balances and revealed the most common types (eg investment banking, retail banking, strategy focused on interbank operations, etc.). The author also identifies different types of business strategies in Ukraine and outlines their main characteristics (for example, universal banking, retail banking, corporate banking, retail financing, investment and frozen banks, etc.). As a result, it was concluded that there is a difference between national and internatinal business strategy models, which is caused by the specific nature of the economic development, the conditions of the crisis, and this opens the way for improvement.
\end{abstract}

Goncharenko, T. (2020). Analysis of models of banking business strategy: international and domestic experience. Economic analysis, 30 (1, Part 1), 42-49.

DOI: https://doi.org/10.35774/econa2020.01.01.042

Keywords: business strategy; business models, bank; banking; banking strategy.

\section{Вступ}

За останні два десятиліття банківський сектор як в Україні, так і в цілому світі, відчув суттєвий вплив різних факторів: поява нових фінансових інструментів, фінансові кризи, зміна регуляторного середовища, що позначилося на підвищенні інтенсивності регулювання банківської діяльності, вимоги щодо інформаційної прозорості, процеси діджиталізації банківської діяльності та активне запровадження фінтех-інновацій тощо. Все це суттєво змінило позиції банків, заставило переглянути ринкові стратегії та бізнесстратегії в цілому.

Питання зміни бізнес-стратегій банків було об'єктом численних досліджень як в міжнародному, так і у вітчизняному просторі. Зокрема, вагомий вклад здійснили група науковців на чолі з Р. Аяді ([1], [2], [3], [4], [5], [6]), дослідження яких були сконцентровані на європейському банківському просторі в до- та після- 
www.econa.org.ua

кризових умовах. Окрім них, слід відмітити й інших зарубіжних дослідників, зокрема Т. Геріга [7], який досліджував зміну банківських бізнес-моделей та похідних ризиків. Серед українських науковців заслуговують на увагу Заруцька О.П. [10], Заяць Е.Л. [11], Корнилюк Р., Корнилюк А. [8], Онищенко Ю.І. [9], Рашкован В. [12] тощо. Незважаючи на численні дослідження в цій сфері, в сучасних постійно змінюваних умовах питання ґрунтовного дослідження зарубіжного досвіду та українських дієвих практик формування бізнес-стратегій банків $€$ достатньо актуальним.

\section{Мета статті}

Метою даної роботи є ґрунтовний аналіз існуючих моделей бізнес-стратегії банків в міжнародному та вітчизняному банківському просторі.

\section{Виклад основного матеріалу дослідження}

Розглянемо основні тенденції зміни бізнесстратегій банків. Більшість авторів наводять докази щодо еволюції бізнес-стратегій банків через зміну показників агрегованих балансів банків. Так Т. Геріг [7] наводить дані щодо зростання для банків США ролі нетрадиційних активів та пасивів, позначених як торгові активи або «інші активи» або «інші зобов'язання», а також суттєве зростання активів та зобов'язань на рахунках в ФРС, при цьому дані свідчать про суттєве скорочення банківського капіталу у 2007 році та його появу лише після 2009 року. Геріг [7] показує, що значна частина цього приросту активів складається 3 цінних паперів, забезпечених активами: сек'юритизовані позики, призначені для продажу чи перепродажу, що не підлягають утриманню на балансах банків протягом довгого періоду часу, що свідчить про факт заміни довгострокових кредитних відносин короткостроковими позиками з метою продажу сек'юритизованих позик на ринку іншим інвесторам. Тобто на банківському ринку США с $з$ початку 2000 років постерігається відхід від традиційних стратегій банкінгу на користь інвестиційної моделі.

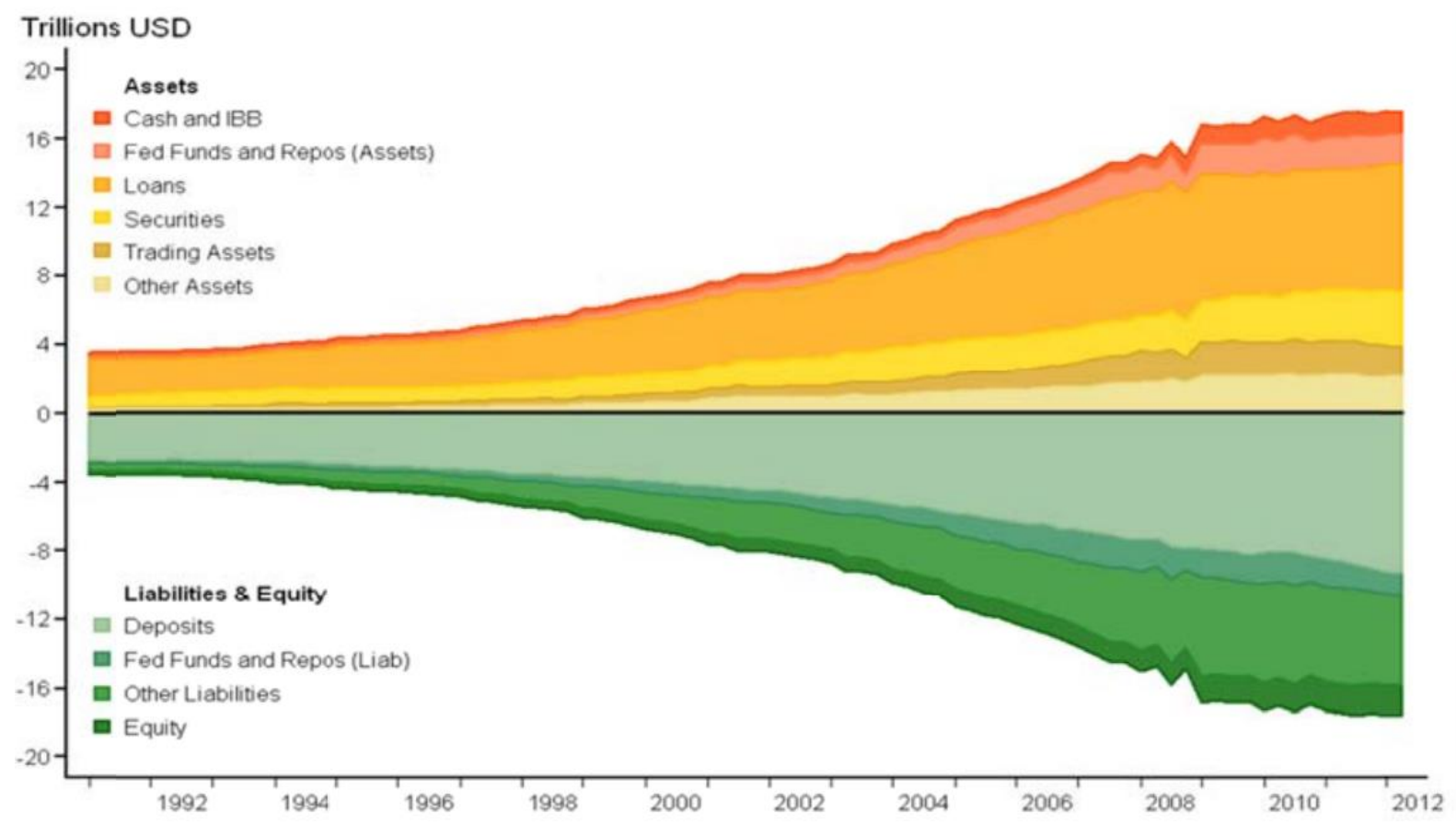

Рис. 1. Тенденції в зміні складових балансів банків США з 1990-2012 рр.

Джерело: [7].

У відповідності до досліджень Р. Аяді та інш. [4] в Європі банки в перед кризовий період також відійшли від своєї традиційної моделі, за якою банки видають позики та несуть ризики самостійно. Поява нових бізнес-моделей в основному зосереджена, хоча і не повністю, на нових інструментах зміни кредитного ризику. У роки, що передували кризі 2007-2009 рр., Р. Аяді та інші [4] виявили декілька тенденцій розвитку банківських бізнес-стратегій в Європі, до яких віднесемо наступні риси:

- банки диверсифікували напрями своєї діяльності, в т.ч. звертаючи увагу на ті сфери ділової активності, які раніше були заборонені регулюванням;

- сек'юритизація позик стала для багатьох банків центральною стратегією бізнесу;

- різко зросли обсяги інвестиційної та торгової діяльності; 
www.econa.org.ua

- банки зменшили обсяги своїх ліквідні активів, оскільки вони отримали більш широкий доступ до ринків фінансування;

- трансформації термінів погашення зобов'язань також різко збільшилася, оскільки більш широко використовувались короткострокові джерела фінансування грошового ринку;

- посилена залежність від фінансових інструментів залучення коштів на ринку капіталів та грошовому ринку;

- тенденція використання кредитних деривативів як засобу перенесення кредитного ризику на контрагента.

Цікаво прослідкувати тенденції в зміні домінуючих моделей в часовому проміжку, що дозволяють нам зробити дослідження Р. Аяді та інших ([1], [2], [3], [4], [5], [6]). Методологія визначення бізнес-стратегій/бізнес-моделей банків Р. Аяді та їі науковим колективом полягає в наступному: основні показники діяльності банків були використані як основа для ідентифікації різних бізнес-стратегій із використанням інструментів кластерного аналізу, до цих показників були включені:

- співвідношення депозитів клієнтів до сукупних активів банку, індикатор вказує на орієнтацію банку на більш традиційні джерела фінансування;

- частка кредитів клієнтів у активах банку, цей показник ідентифікує частку кредитів клієнтів небанківським клієнтам, що вказує, аналогічно з попереднім показником на домінування у банку традиційних банківських операцій;

- частка торгових активів у сукупних активах банку, більше значення показника вказує на активну інвестиційну діяльність, та схильність до ринкових ризиків та ризиків ліквідності;

- частка кредитів банкам у сукупних активах, індикатор вимірює масштаб міжбанківської діяльності та вимірює рівень ризиків, пов'язаних із взаємопов'язаністю в банківському секторі;

- частка суми деривативів у активах банку, цей показник відображає всі позитивні та негативні деривативи банку, які часто визначаються як один із ключових (і найбільших) фінансових ризиків банків з великими інвестиціями та торгівельною діяльністю;

- співвідношення реального акціонерного капіталу у вигляді звичайних акцій до активів банку, індикатор фокусується на найбільш збиткопоглинаючій частині структури капіталу банку, забезпечуючи уявлення про ставлення до ризику банку та рівень його левереджу;

- частка активів в інших банках в сукупних активах, цей показник визначає частку зобов'язань інших банків, включаючи депозити, заборгованість та кошти, отримані від центральних банків, банки з більшими вимогами до міжбанківського фінансування, часто через надмірну залежність від короткострокового фінансування, стикалися 3 серйозними проблемами на ранніх етапах кризи;

- співвідношення боргових зобов'язань до активів, цей індикатор, обчислений шляхом відрахування з загальних зобов'язань депозитів клієнтів, зобов'язань банку, загальної суми власного капіталу та від'ємної справедливої вартості всіх похідних цінних паперів, дає загальну інформацію про вплив банку на ринкове фінансування;

- частка активів розміщених в національній економіці (у відсотках від активів) - менший показник співставляється 3 меншими транскордонними ризиками, однак показує більший ризик концентрації (низький рівень географічної диверсифікації).

Авторами в різні періоди використовувалися той чи інший набір вище перелічених показників для ідентифікації бізнес-стратегій банків. Як результат Центр європейських політичних досліджень періодично публікує на своєму сайті звіт з моніторингу бізнес-моделей банків Європи, що дозволяє проаналізувати існуючі бізнес-стратегії банків в Європейському союзі, а також зробити висновок про зміну методології ідентифікації бізнес-стратегій банків.

При аналізі бізнес-стратегій українських банків традиційно прийнято диверсифікувати стратегії в залежності від орієнтації на корпоративний сектор (юридичних осіб) та сектор домогосподарств (фізичних осіб), враховуючи такий розподіл серед українських науковців (Корнілюк Р. [8], Оніщенко Ю. [9], Оніщенко Ю. та інші [11]) прийнято виділяти наступні бізнес-стратегії банків:

- універсальний банкінг - діяльність банків диверсифікована та спрямована на всі сегменти ринку банківських послуг;

- рітейл банкінг - орієнтація на операції 3 фізичними особами, як депозитні так i кредитні;

- корпоративний банкінг - орієнтація як в зобов'язаннях так і в розміщенні активів на корпоративний сектор економіки - юридичні особи;

- «рітейл фінансування - корпоративне кредитування» (Оніщенко Ю. [9]), іноді можна зустріти назву фокусований рітейл, або «традиційний» (Оніщенко Ю. та інші [11]).

- інвестиційні, які нещодавно почали виділяти (Оніщенко Ю. та інші [11]) в банківській системі України.

- заморожені банки (Корнілюк Р. [8]) - діяльність яких майже не ведеться, характеризуються аномально низькими показниками капіталу та обсягами активних операцій. 
www.econa.org.ua

Таблиця 1. Аналіз існуючих бізнес-стратегій банків в Європейському Союзі

\begin{tabular}{|l|l|c|c|c|c|}
\hline \multirow{2}{*}{ № } & \multicolumn{1}{|c|}{ Назва бізнес-стратегії банку } & \multicolumn{3}{c|}{ Роки дослідження } \\
\cline { 3 - 6 } & \multicolumn{1}{|c|}{$\begin{array}{c}2006- \\
2009\end{array}$} & $\begin{array}{c}2006- \\
2010\end{array}$ & $\begin{array}{c}2006- \\
2013\end{array}$ & $\begin{array}{c}2006- \\
2014\end{array}$ & $\begin{array}{c}2005- \\
2017\end{array}$ \\
\hline 1 & Інвестиційий банкінг & + & + & + & + \\
\hline 2 & Стратегія орієнтована на міжбанківські операції & + & + & + & + \\
\hline 3 & Рітейл банкінг & + & & & + \\
\hline 4 & $\begin{array}{l}\text { Рітейл банкінг з орієнтацією на депозити та кредити } \\
\text { клієнтів }\end{array}$ & + & + & + \\
\hline 5 & $\begin{array}{l}\text { Рітейл банкінг з орієнтацією на диверсифіковане } \\
\text { фінансування з грошового ринку та ринку капіталів } \\
\text { тарозміщення в кредити клієнтів }\end{array}$ & & + & + \\
\hline 6 & $\begin{array}{l}\text { Рітейл банкінг з орієнтацією на фінансування за } \\
\text { рахунок депозитів клієнтів та диверсифіковане } \\
\text { розміщення активів }\end{array}$ & + & + \\
+
\end{tabular}

Джерело: побудовано автором на основі Р. Аяді та інших [1], [2], [3], [4], [5], [6].

Дослідження ринкової поведінки банків (їх бізнес-стратегій/бізнес-моделей) проводилось також і фахівцями Національного банку України (Рашкован В., Покідін Д. [12]), основні показники діяльності банків були використані як основа для ідентифікації різних бізнес-стратегій: активи/філії (характеризує інтенсивність використання мережі філій, гіпотеза - банки орієнтовані на роздрібний сегмент будуть мати менший показник, ніж банки орієнтовані на корпоративних клієнтів); середній термін погашення кредитів (за думкою авторів корпоративний сегмент бізнесу характеризується низькими строками кредитування); середній розмір кредитів (роздрібне кредитування повинно характеризуватися невеликими обсягами кредитів, натомість для банків, що кредитують корпоративний сектор цей індикатор буде значно більше); частка власного капіталу та субординованого боргу та частка кредитів (без урахування міжбанківських кредитів) у активах (ці індикатори характеризують традиційність моделі банківського бізнесу); частка роздрібних кредитів та частка роздрібних депозитів (високі значення цих індикаторів свідчать про активну роботу банку в роздрібному сегменті ринку).

В результаті кластеризації 3 застосуванням самоорганізаційних карт Коханена авторами (Рашкован В., Покідін Д. [12]) було виділено 6 типів бізнес-стратегій банків:

1. Роздрібний, якому відповідає найбільша частка роздрібних кредитів; велика частка роздрібних депозитів, найнижчий середній розмір кредитів, найдовший строк до погашення кредитів і найбільша кількість банківських філій.

2. Стратегія «фінансування від домогосподарств активи корпораціям», який характеризується великою часткою роздрібних депозитів, при цьому незначною часткою роздрібних кредитів, натомість банки цього кластеру мають велику частку корпоративних кредитів;

3. Універсальний банкінг, для якого характерне поєднання кредитів та некредитних активів, при цьому кредити надаються як роздрібному, так і корпоративному кластерам, фінансування - диверсифіковане (частка роздрібних депозитів велика, але менше ніж у попередніх моделях;

4. Корпоративна бізнес-стратегія передбачає відмову від роздрібних кредитів та депозитів, зосередження на обслуговуванні тільки корпоративних клієнтів, характеризується найбільшим середнім розміром кредитів і найкоротшим строком до погашення за кредитами, банкам, що притримуються цієї стратегії не потрібні філії, що виокремлює їх за показником «активи/кількість філій»

5. Заморожені/Невизначені банки, має різнорідні характеристики за структурою активів і зобов'язань, при цьому характерною для цієї стратегії ознакоє $€$ велика частка власного капіталу та субординованого боргу.

6. Інвестиційні банки, які мають найменшу частку кредитів серед усіх, а більшість активних операцій цих банків - некредитні.

В роботі (Заруцька О. [10]) станом 01.01.2019 р. за допомогою програмного комплексу Viscovery SOMine, без участі користувача, методом структурно-функціональних груп, що передбачає формування однорідних груп банків за значеннями фінансових показників з використанням нейронних мереж-самоорганізаційних карт Кохонена, авторкою отримано 12 різних за розмірами груп із неоднаковою кількістю банків. 
www.econa.org.ua

Таблиця 2. Опис характеристик бізнес-стратегій банків України за станом на 01.01.2019 р.

\begin{tabular}{|c|c|c|c|}
\hline $\begin{array}{c}\text { № } \\
\Pi / \Pi\end{array}$ & \begin{tabular}{|c|} 
Тип бізнес- \\
стратегії банку
\end{tabular} & Характеристика значень фінансових показників банків & Короткий опис \\
\hline 1 & AcN-LiN & $\begin{array}{l}\text { Активи - корпоративні у національній валюті. } \\
\text { Зобов'язання - індивідуальні у національній валюті. }\end{array}$ & $\begin{array}{l}\text { Невеликі банки з середніми } \\
\text { характеристиками, національна } \\
\text { валюта }\end{array}$ \\
\hline 2 & Acl-Lisl & $\begin{array}{l}\text { Активи - корпоративні у іноземній валюті, Зобов'язання } \\
\text { - індивідуальні в іноземній валюті. }\end{array}$ & $\begin{array}{l}\text { Невеликі банки з середніми } \\
\text { характеристиками, іноземна валюта }\end{array}$ \\
\hline 3 & Acil-Lp-PBI & $\begin{array}{l}\text { Великі проблемні, відкрита валютна позиція, активи - } \\
\text { корпоративні та індивідуальні в іноземній валюті. } \\
\text { Зобов'язання - поточні. }\end{array}$ & $\begin{array}{l}\text { Великі банки з кредитними і } \\
\text { валютними ризиками, іноземна } \\
\text { валюта }\end{array}$ \\
\hline 4 & Avs-Lp & $\begin{array}{l}\text { Активи - високоліквідні пінні папери. Зобов'язання - } \\
\text { поточні. }\end{array}$ & $\begin{array}{l}\text { Середні банки з надлишковими } \\
\text { високоліквідними активами та } \\
\text { операційними ризиками }\end{array}$ \\
\hline 5 & Acil-Lml-BI & $\begin{array}{l}\text { Великі, відкрита валютна позиція. Активи - } \\
\text { корпоративні та індивідуальні у іноземній валюті. } \\
\text { Зобов'язання - міжбанківські кредити в іноземній } \\
\text { валюті. }\end{array}$ & $\begin{array}{l}\text { Великі банки з валютними } \\
\text { ризиками, іноземний капітал. }\end{array}$ \\
\hline 6 & Amv-Lm-D & $\begin{array}{l}\text { Активи - високоліквідні, міжбанківські кредити, } \\
\text { Зобов'язання - міжбанківські кредити, підвищені } \\
\text { ставки }\end{array}$ & $\begin{array}{l}\text { Невеликі банки на ринку } \\
\text { міжбанківських кредитів, процентні } \\
\text { ризики. }\end{array}$ \\
\hline 7 & AiN-LiN-AK & $\begin{array}{l}\text { Активи - індивідуальні у національній валюті, } \\
\text { Зобов'язання - індивідуальні у національній валюті, } \\
\text { підвищені адміністративні витрати та комісійні доходи. }\end{array}$ & $\begin{array}{l}\text { Середні банки роздрібного } \\
\text { кредитування, національна валюта }\end{array}$ \\
\hline 8 & As-Lcp-D & $\begin{array}{l}\text { Активи - цінні папери, Зобов'язання - корпоративні } \\
\text { поточні, підвищені ставки }\end{array}$ & $\begin{array}{l}\text { Середні банки з поточними } \\
\text { ресурсами та цінними паперами у } \\
\text { активах. }\end{array}$ \\
\hline 9 & AcN-LcsN-S & $\begin{array}{l}\text { Малі. Активи - корпоративні у національній валюті. } \\
\text { Зобов'язання - корпоративні у національній валюті. }\end{array}$ & Малі кептивні банки. \\
\hline 10 & AcN-LmN-P & $\begin{array}{l}\text { Активи - корпоративні у національній валюті. } \\
\text { Зобов'язання - міжбанківські кредити у національній } \\
\text { валюті. Проблемні }\end{array}$ & Невеликі проблемні банки \\
\hline 11 & Am-Lml-SI & $\begin{array}{l}\text { Малі. Відкрита валютна позиція. Активи - міжбанківські } \\
\text { кредити. Зобов'язання - міжбанківські кредити в } \\
\text { іноземній валюті. }\end{array}$ & $\begin{array}{l}\text { Малі банки на ринку } \\
\text { міжбанківського кредитування. } \\
\text { Валютні ризики. }\end{array}$ \\
\hline 12 & As-LI-BIP & $\begin{array}{l}\text { Найбільші. Відкрита валютна позиція. Активи - цінні } \\
\text { папери. Зобов'язання - в іноземній валюті. }\end{array}$ & $\begin{array}{l}\text { Найбільші банки з кредитними та } \\
\text { валютними ризиками та цінними } \\
\text { паперами у активах. }\end{array}$ \\
\hline
\end{tabular}

Джерело: [10].

\section{Висновки та перспективи подальших розвідок}

Таким чином, в світовій практиці класифікація бізнес-стратегій банків відбувається виходячи зі специфіки роботи банків: орієнтація на традиційні банківські операції (депозити та кредити) чи залучення та розміщення коштів на міжбанківському чи фінансовому ринку в цілому, натомість для українських реалій інвестиційна стратегія (активні та пасивні операції на фінансовому ринку) з'явилася в аналізі лише останнім часом, натомість стратегія орієнтації на міжбанківські операції також присутня в діяльності деяких банківських установ України, однак рітейл банкінг в українських умовах прийнято диверсифікувати в залежності від сектору з яким працюють банки роздрібний (фізичні особи) чи корпоративний (юридичні особи), та можливі перехресні зв'язки «фінансування за рахунок депозитів фізичних осіб - кредитування юридичних осіб». В Україні остання стратегія активно унаслідувалася банками до кризи 2014 року, охоплювала приблизно половину банківської системи та ніс ризик кредитування пов'язаних осіб. Також нехарактерною для Європи та Америки $€$ стратегія заморожування діяльності, що може відбуватися з багатьох причин: банк не здійснив масштабування своїх операцій; банк неактивний, створений для продажу (банк-банківська ліцензія); 
www.econa.org.ua

банк займається нетиповими для традиційних i інвестиційних банків видами діяльності. 3 метою кластеризації з урахуванням валютних ризиків, що також $\epsilon$ більш характерним для України використовують вид валюти при аналізі зобов'язань та активів банків. Виділення бізнесстратегій банків відбувається шляхом застосування кластерного аналізу різного типу складності (ксередніх, карти Коханена тощо). Bсе вищезазначене дозволяє стверджувати про відсутність єдиного підходу до визначення бізнесстратегій банків та розкриває шляхи щодо вдосконалення існуючих.

\section{СПИСОК ВИКОРИСТАНИХ ДЖЕРЕЛ}

1. Ayadi R. Banking Business Models: Definition, Analytical Framework and Financial Stability Assessment. Springer, 2019. URL: https://rymayadi.com/bankingbusiness-models-definitionanalytical-framework-and-financialstability-assessment.

2. Ayadi R., de Groen W. P. Banking Business Models Monitor 2014: Europe, Montreal, Joint Centre for European Policy Studies (CEPS) and International Observatory on Financial Service Cooperatives (IOFSC) publication, 2014. URL: https://www.ceps.eu/cepspublications/banking-businessmodels-monitor-2014-europe.

3. Ayadi R., de Groen, W. P. Banking Business Models Monitor 2015: Europe, Montreal, IRCCF, 2016. URL: https://www.ceps.eu/cepspublications/banking-businessmodels-monitor-2015-europe.

4. Ayadi R., Arbak E., de Groen W. P. Business Models in European Banking: A pre and postcrisis screening, Centre for European Policy Studies (CEPS), Brussels, 2011. URL:

https://www.ceps.eu/cepspublications/business-modelseuropean-banking-pre-and-postcrisis-screening/

\section{REFERENCES}

1. Ayadi, R. (2019). Banking Business Models: Definition, Analytical Framework and Financial Stability Assessment. Springer. Retrieved from:

https://rymayadi.com/bankingbusiness-models-definitionanalytical-framework-and-financialstability-assessment.

2. Ayadi, R. and de Groen, W. P. (2014). Banking Business Models Monitor 2014: Europe, Montreal, Joint Centre for European Policy Studies (CEPS) and International Observatory on Financial Service Cooperatives (IOFSC) publication. Retrieved from: https://www.ceps.eu/cepspublications/banking-businessmodels-monitor-2014-europe.
5. Ayadi R., Arbak E., de Groen W.P. Regulation of European Banks and Business Models: Towards a new paradigm? Centre for European Policy Studies (CEPS), Brussels, $2012 . \quad$ URL: https://www.ceps.eu/cepspublications/regulation-europeanbanks-and-business-modelstowards-new-paradigm.

6. Ayad R., Cucinelli D., de Groen W.P. Banking business models monitor 2019: EuropePerformance, Risk, Response to Regulation and Resolution: 2005-2017. Centre for European Policy Studies (CEPS), Brussels, 2019. URL: https://www.ceps.eu/cepspublications/bankingbusinessmodels-monitor-2019europe.

7. Gehrig T. Changing Business Models in Banking and Systemic Risk, 2015. 10.1007/978-3-658-05014-6_8.

8. Kornyliuk R., Kornyliuk A. Ukrainian Banks' business models under systemic risk, CEUR Workshop Proceedings, 2018, Volume 2105, P. 124-138. URL: https://www.researchgate.net/publ ication/325973869_Kornyliuk_R_Ko rnyliuk_A_2018_Ukrainian_Banks'_ business_models_under_systemic_r isk_CEUR_Workshop_Proceedings_ Volume_2105_2018_Pages_124138.

3. Ayadi, R. and de Groen, W. P. (2016). Banking Business Models Monitor 2015: Europe, Montreal, IRCCF. Retrieved from: https://www.ceps.eu/cepspublications/banking-businessmodels-monitor-2015-europe.

4. Ayadi, R., Arbak, E., and de Groen, W. P. (2011). Business Models in European Banking: A pre and postcrisis screening, Centre for European Policy Studies (CEPS), Brussels. Retrieved from: https://www.ceps.eu/cepspublications/business-modelseuropean-banking-pre-and-postcrisis-screening.
9. Onyshchenko Y. Banking business models in Ukrainian banking system. Baltic Journal of Economic Studies. 2015. Volume 1. № 2. P. 115-121.

10. Заруцька О. П. Оцінювання бізнесмоделей банків України за методом структурнофункціональних груп. URL: http://uninbank.dp.ua/news/665otsinyuvannya-biznes-modelejbankiv-ukrajini-za-metodomstrukturno-funktsionalnikh-grup.

11. Онищенко Ю. І., Заяць Е. Л. Теоретичні підходи до визначення дефініції «бізнес-модель банку». International Scientific Conference Digital and Innovative Economy: Processes, Strategies, Technologies: Conference Proceedings, January 25. 2019. Kielce, Poland: Baltija Publishing. P. 101-104.

12. Рашкован В., Покідін Д. Кластерний аналіз бізнесмоделей українських банків: застосування нейронних мереж Кохонена. Вісник Національного банку України. 2016. № 238. С. 13$40 . \quad$ URL: http://nbuv.gov.ua/UJRN/Vnbu_20 16_238_4.
5. Ayadi, R., Arbak, E., and de Groen, W. P. (2012). Regulation of European Banks and Business Models: Towards a new paradigm? Centre for European Policy Studies (CEPS), Brussels. Retrieved from: https://www.ceps.eu/cepspublications/regulation-europeanbanks-and-business-modelstowards-new-paradigm. 


\section{www.econa.org.ua}

6. Ayadi, R., Cucinelli, D., de Groen, W. P. (2019). Banking business models monitor 2019: EuropePerformance, Risk, Response to Regulation and Resolution: 20052017. Centre for European Policy Studies (CEPS), Brussels. Retrieved fromhttps://www.ceps.eu/cepspublications/banking-

businessmodels-monitor-2019europe.

7. Gehrig, T. (2015). Changing Business Models in Banking and Systemic Risk. 10.1007/978-3-658-05014 6 8.
8. Kornyliuk, R., \& Kornyliuk, A. (2018). Ukrainian Banks' business models under systemic risk, CEUR Workshop Proceedings, 2105, 124138. Retrieved from https://www.researchgate.net/publ ication/325973869_Kornyliuk_R_Ko rnyliuk_A_2018_Ukrainian_Banks'_ business_models_under_systemic_r isk_CEUR_Workshop_Proceedings_ Volume_2105_2018_Pages_124138

9. Onyshchenko, Y. (2015). Banking business models in Ukrainian banking system. Baltic Journal of Economic Studies, 1(2), 115-121 [in Ukrainian].

10. Zarutska, O. P. (2018). Estimation of business models of Ukrainian banks by the method of structural and functional groups. Retrieved from: http://uninbank.dp.ua/news/665otsinyuvannya-biznes-modelejbankiv-ukrajini-za-metodomstrukturno-funktsionalnikh-grup [in Ukrainian].
11. Onyshchenko, Y. I., \& Zayats, E. L. (2019). Theoretical approaches to defining the definition of "business model of the bank". International Scientific Conference Digital and Innovative Economy: Processes, Strategies, Technologies: Conference Proceedings. Kielce, Poland: Baltija Publishing, 101-104 [in Ukrainian].

12. Rashkovan, V., Pokidin, D. (2016) Cluster analysis of business models of Ukrainian banks: application of Kohonen neural networks. Bulletin of the National Bank of Ukraine, 238 13-40. Retrieved from http://nbuv.gov.ua/UJRN/Vnbu_20 16_238_4 [in Ukrainian]. 